\title{
Inhibition Effect ofCopper (II) Theophylline Nanocomplex on Phosphodiesterase (PDE) Enzyme Activity in Human Serum of Iraqi Patients with Asthma Disease
}

\author{
Zainab Sabri Abbas ${ }^{1}$, Ahmad Hussein Ismail ${ }^{2}$, Hassanain Kamil Al-Bairmani ${ }^{2}$, \\ Ahmed Mahdi Rheima, ${ }^{3,4}$, Ameer Radhi Sultan ${ }^{5}$, Srwa Hashim Mohammed ${ }^{6}$ \\ ${ }^{1}$ Kut University College, Dentistry Department , Al-Kut, Wasit , Iraq, 52001. \\ ${ }^{2}$ Mustansiriyah University, College of Science, Department of Chemistry. Iraq. \\ ${ }^{3}$ Wasit University, College of Science, Department of Chemistry, Kut, Iraq. \\ ${ }^{4}$ College of technical engineering, The Islamic University, Najaf, Iraq \\ ${ }^{5}$ Department of Chemistry Lab, Al-lmamine Al-Kadhumain Medical City Hospital, Baghdad, Iraq. \\ ${ }^{6}$ Garmian University, College of Education, Department of Chemistry. Kalar, Iraq. \\ C Corresponding author. E-mail: arahema@uowasit.edu.iq
}

Received: Aug. 3, 2020; Accepted: Aug. 5, 2021; Published: Nov. 2, 2021

Citation: Zainab Sabri Abbas, Ahmad Hussein Ismail, Hassanain Kamil Al-Bairmani, Ahmed Mahdi Rheima, Ameer Radhi Sultan, and Srwa Hashim Mohammed,Inhibition Effect of Copper (II) Theophylline Nanocomplex on Phosphodiesterase (PDE) Enzyme Activity in Human Serum of Iraqi Patients with Asthma Disease. Nano Biomed. Eng., 202I, 13(4): 364-37I.

DOI: 10.5101/nbe.v13i4.p364-371.

\begin{abstract}
Copper (II) theophylline $\left[\mathrm{Cu}(\mathrm{THP})_{2}\left(\mathrm{H}_{2} \mathrm{O}\right)_{4}\right]$ complex in nanoscale has synthesized by ultrasonic sonication method. This method was used in the development of smaller, dispersed, and unaggregated nanoparticles (NPs). The structure of nanocomplex was described and suggested by the molar conductance, Fourier transform infrared spectroscopy (FTIR), ultraviolet-visible spectroscopy (UVVis), solubility, atomic fire absorption, and C.H.N. elemental analysis as octahedral geometry. The size and morphology of nanocomplex measured by transmission electron microscopy (TEM) were $20 \mathrm{~nm}$. The nanocomplex was studied on phosphodiesterase enzyme activity in human serum of Iraqi patient>s asthma disease. The results showed a highly significant $(\mathrm{p}<0.01)$ increase in the serum levels of phosphodiesterase enzyme activity in asthma patients (mean $=14.939 \pm 3.021 \mathrm{ng} / \mathrm{mL}$ ) compared with a control group (mean $=9.974 \pm 2.032 \mathrm{ng} / \mathrm{mL}$ ). The result also showed a highly significant $(\mathrm{p}$ $<0.01$ ) decrease in the serum levels of phosphodiesterase activity in patients of asthma disease with theophylline (mean $=11.253 \pm 2.479 \mathrm{ng} / \mathrm{mL}$ ) compared to serum patients without nano and control groups. It is vital that the result showed a highly significant $(\mathrm{p}<0.01)$ decrease in the serum levels of phosphodiesterase activity in patients of asthma disease with copper nano complex (mean = $9.563 \pm 2.082 \mathrm{ng} / \mathrm{mL}$ ) compared in patients of asthma disease with and without theophylline. As for comparing asthma disease with copper nano complex and control group, the result showed there was no significant effect $(\mathrm{p}>0.05)$.
\end{abstract}

Keywords: Nanocomplex, Asthma, Phosphodiesterase (PDE), Theophylline, Ultrasonic sonication method

\section{Introduction}

Phosphodiesterase (PDE) is a hydrolytic enzyme that has been distributed in mammalian tissue worldwide and plays an essential role in the hydrolysis of cAMP and cGMP cell signals. PDEs can selectively control different cellular functions thanks to their versatility, enabling further distribution at the cellular 
and subcellular levels. These are new therapeutic targets of inflammation because of their essential role in intracellular signalling [1]. The nanocomplexes have characteristic physical, chemical, and biological applications, as studies have shown [2-12]. Nanotechnology has recently shown interest properties in the medical field through new constructions with practical feasibility [13-18]. Asthma is a chronic airway inflammatory condition in which many cells and cellular functions are involved: T lymphocytes, neutrophils, mast cells, eosinophils, macrophages, and epithelial cells in particular. This inflammation leads to episodes repeated, particularly at night or early morning, lead to airway lightness and the coughing of susceptible people. The incidents usually involve significant but unpredictable airflow barriers, often reversible or therapeutic spontaneously [19, 20]. The inflammation also raises the current bronchial hyperreactive to a variety of stimuli. In some patients with asthma, airflow restriction reversibility may not be complete. This resulted in significant increases in disease morbidity and mortality [21]. Early asthma concepts include airway obstruction that can be alleviated by medication and bronchial hyperresponsive (BHR) as the most significant symptoms characterizing asthma from other similar conditions, including chronic bronchitis and chronic obstructive pulmonary diseases (COPD) [22-24]. In recent times the concept of asthma has been strengthened by an understanding of the chronic inflammation of an airway submucosa of the asthmatic patients, which are the significant causes of asthma symptoms by traditional inflammatory infiltrators. Also, loss of airway blockage reversibility is known as a chronic inflammatory long-term consequence [25]. Also, a group of purine alkaloids is made up of methylxanthines. These are essential ingredients used in many plant species and foodstuffs, including tea, coffee beans, cocoa, and cola nuts [2629].

Neonatal apnoea is produced by caffeine and theophylline (THP), bronchial and asthma treatment. Moreover, they are part of the drug mix for pain, cold, and cough daily [30]. Theophylline has been shown to induce bronchodilation through a chemical process, which contracts the smooth muscle. This results through inhibition of the PDE action, which breaks down circular nucleotides into the cell and increases cyclic monophosphate adenosine (cAMP) and cyclic monophosphate guanosine (cGMP) extracellular levels. This results in an extension of how the muscles are smooth [31]. Due to its bronchodilatory and antiinflammatory effects, theophylline, a non-selective phosphodiesterase inhibitor, has been used for several years to treat asthma. However, it was gradually restricted because of a low therapeutic index and side effects [32]. The current study aims to develop asthma therapeutic by converting theophylline into an inorganic complex with copper ion in nanoscale, and It is clinically applied to patients with chronic asthma.

\section{Experimental}

\section{Materials}

Theophylline $\left(\mathrm{C}_{7} \mathrm{H}_{8} \mathrm{~N}_{4} \mathrm{O}_{2}\right)$ purty $99 \%$, sodium hydroxide $(\mathrm{NaOH})$ purty $98 \%$, copper chloride $\left(\mathrm{CuCl}_{2}\right)$ purty 99\%, and dimethyl sulfoxide $\left(\mathrm{C}_{2} \mathrm{H}_{6} \mathrm{OS}\right)$ purty 97\% were purchased from Sigma-Aldrich. Through the preliminary steps, de-ionized water was used.

\section{Synthesis of copper (II) nanocomplex}

medical nanocomplex of $\mathrm{Cu}(\mathrm{II})$ with theophylline (THP) as a ligand was synthesized using the ultrasonic sonication (20 KHz, Dispersed) method as depicted in Scheme 1. Accordingly, theophylline (0.004 mol) was dissolved in $40 \mathrm{~mL}$ fresh $\mathrm{NaOH}(0.004 \mathrm{~mol})$ solution to prepare the medical ligand's sodium salt $(0.1 \mathrm{M})$. The obtained solution was heated up to $70{ }^{\circ} \mathrm{C}$, and then copper (II) chloride (0.002 mol in $40 \mathrm{~mL}$ ) was added to an aqueous solution. The solution mixture was kept under ultrasonic sonication for $3 \mathrm{~h}$ at $70{ }^{\circ} \mathrm{C}$. Subsequently, crystals of good quality emerged at room temperature and overnight incubation. Novel complexes isolated by filtration by filter paper then washed with de-ionized water and dried well in air [16, 33]. Complex [Cu(THP $\left.)_{2}\left(\mathrm{H}_{2} \mathrm{O}\right)_{4}\right]$ : color: Greenish blue; Anal. Calc. for $\mathrm{C}_{14} \mathrm{H}_{18} \mathrm{~N}_{8} \mathrm{O}_{6} \mathrm{CuCl}_{2}$ :C, 34.04; H, $4.46 \mathrm{~N}$, 22.69; $\mathrm{Cu}, 12.87$. Found: C, 35.13; H, 4.22; N, 21.51; Mn, $12.02 \%$.

\section{Sample collection Specimens collection}

A total sample of 40 patients with chronic airway inflammatory (Asthma) was obtained from Allergy and Asthma center (Babylon). Who matched forty (40) standard control included in the present study was collected from various places. A $5 \mathrm{~mL}$ of venous blood samples have been taken from all the Patients and control by plastic disposable syringes and were allowed clotting at room temperature for 10 minutes 
<smiles>Cn1c(=O)c2[nH]cnc2n(C)c1=O</smiles><smiles>Cn1c(=O)c2c(ncn2[18O])n(C)c1=O</smiles>

(2)

$$
+\underset{\text { (1) }}{\mathrm{CuCl}_{2}} \stackrel{\mathrm{H}_{2} \mathrm{O}}{\stackrel{\mathrm{H}^{2} \text { strasonic, }}{\text { sonication }}}
$$

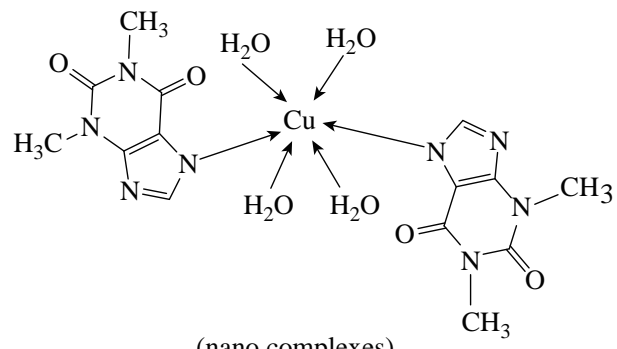

$+2 \mathrm{NaCl}$

Scheme 1 Copper (II) nanocomplex synthesized at $70^{\circ} \mathrm{C}$.

from the patients and healthy controls then centrifuged at $(3000 \mathrm{x}$ g) for $5 \mathrm{~min}$. The serum samples have isolated and preserved at $\left(-20^{\circ} \mathrm{C}\right)$ to study later [4].

\section{Division of serum samples}

Group one: Control group included no previous disease, which may interfere with the parameters analyzed in this study and preserved at $\left(-20^{\circ} \mathrm{C}\right)$ to study later. This group had 40 Control.

Group two: patients group included; chronic airway inflammatory (Asthma) and preserved at $\left(-20^{\circ} \mathrm{C}\right)$ to later study. This group included 40 patients.

Group three: patients group with nanomedicine complex [Cu(THP $\left.)_{2}\left(\mathrm{H}_{2} \mathrm{O}\right)_{4}\right]$ were mixed $1: 1$, and preserved at $\left(-20^{\circ} \mathrm{C}\right)$ to study later. This group included 40 patients.

Group four: patients group with only theophylline were mixed $1: 1$. And it was preserved at $\left(-20^{\circ} \mathrm{C}\right)$, to later study for comparison with group three. This group included 40 patients.

\section{Determination of phosphodiesterases (PDE)}

Phosphodiesterases (PDEs) are hydrolytic enzymes that destroy cyclic extracellular nucleotides. By changing the concentration of these second emissaries, PDEs control the cell and subcellular function. PDEs are distributed all around the human body in a compartmentalized way. The Phosphodiesterases (PDEs) were determined by the ELISA technique using the human ELISA Kit supplied from Melsin medical co. China. This kit includes a microtiter plate that is pre-coated with anticorps. Samples, HRP conjugated antibody to wells, and norm were introduced. Chromogen Solution A and B were added after gestation and cleaning to remove the unenhanced enzyme. The liquid's color will turn blue. The hue finally turns yellow at the influence of acid. The spectrophotometrical color change is measured at $450 \mathrm{~nm}$ wavelength. Phosphodiesterase concentration (PDE) in the samples is then compared with the O.D. The standard curve of the samples [34].

\section{Characterisation}

Copper nano complex was characterized via some devices. Transmission electron microscope (TEM) type JEOL JEM-2100 had used to determine the size and morphology of the copper nanocomplex. The U.V-Vis spectrum (Shimadzu UV-Vis $160 \mathrm{~V}$ ) helped us to predict the suggested geometry according to the shape and number of observed peaks. FT-IR spectra (Shimadzu FTIR) were used to define the coordination sits. ELISA technique was used to measure the Inhibition of Phosphodiesterase (PDE).

\section{Statistical analysis}

IBM USA SPSS software V-24 evaluated the data. The statistical carry out by one-way analysis of variance. The student t-test has been used to assess differences in mean values between the studied groups in all biochemical studies, where $\mathrm{P}<0.01$ was considered highly significant.

\section{Results and Discussion Copper (II) nanocomplex characterisation}

The FTIR spectrum of theophylline (Fig. 1) showed an absorption band at $\left(3120 \mathrm{~cm}^{-1}\right)$, which referred to $\mathrm{v}$ $(\mathrm{NH})$, which disappeared in the FTIR spectra of copper 
nano complex (Fig. 2). This indicated that the (NH) group was involved in coordinating theophylline with the copper ion. An additional broad absorption band could be seen in the region of $3560-3350 \mathrm{~cm}^{-1}$ for the prepared complex (hydroxyl group), representing the water stretching vibration, indicating water molecules' involvement in coordination. A new band in the complex appeared at $569-573 \mathrm{~cm}^{-1}$ referred to as metal coordination (N-M). Furthermore, all vibration bands in the nanocomplex shifted to a lower frequency than free theophylline due to hydrogen bonds of water molecules with the carbonyl and amine groups [35].

The electronic spectrum of [Cu(THP $\left.)_{2}\left(\mathrm{H}_{2} \mathrm{O}\right)_{4}\right]$ complex (Fig. 3) showed a broad absorption band at $678 \mathrm{~nm}\left(14749 \mathrm{~cm}^{-1}\right)$, which referred to ${ }^{2} \mathrm{Eg} \rightarrow{ }^{2} \mathrm{~T}_{2} \mathrm{~g}$ transition, this band position is in good accord with the configuration of the octahedral. Therefore, we can suggest an octahedral structure around the $\mathrm{Cu}(\mathrm{II})$ ion from the above data and those obtained from elementary analysis (C.H.N.), FTIR, and flame atomic absorption.

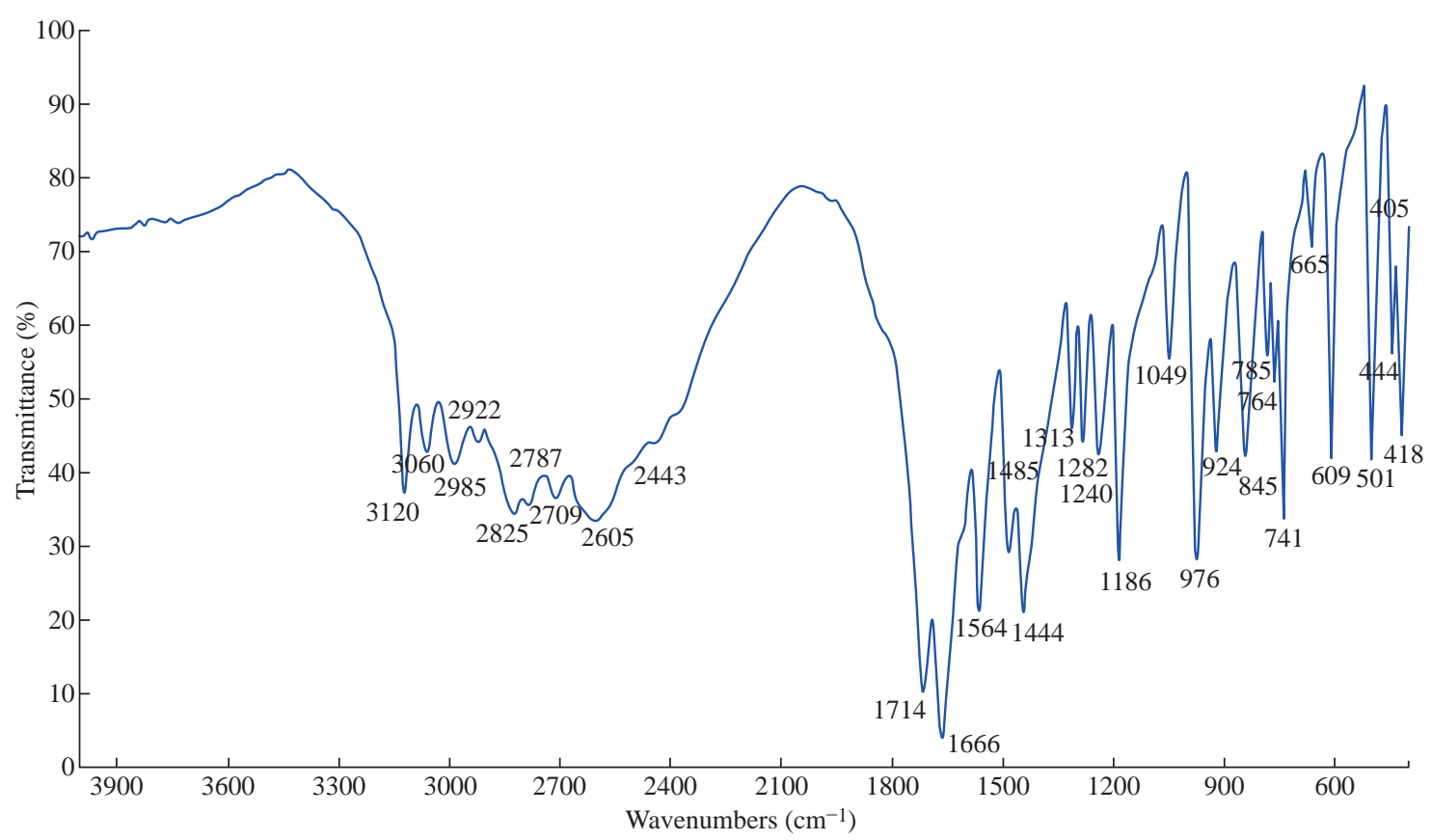

Fig. 1 FTIR spectrum of theophylline (THP).

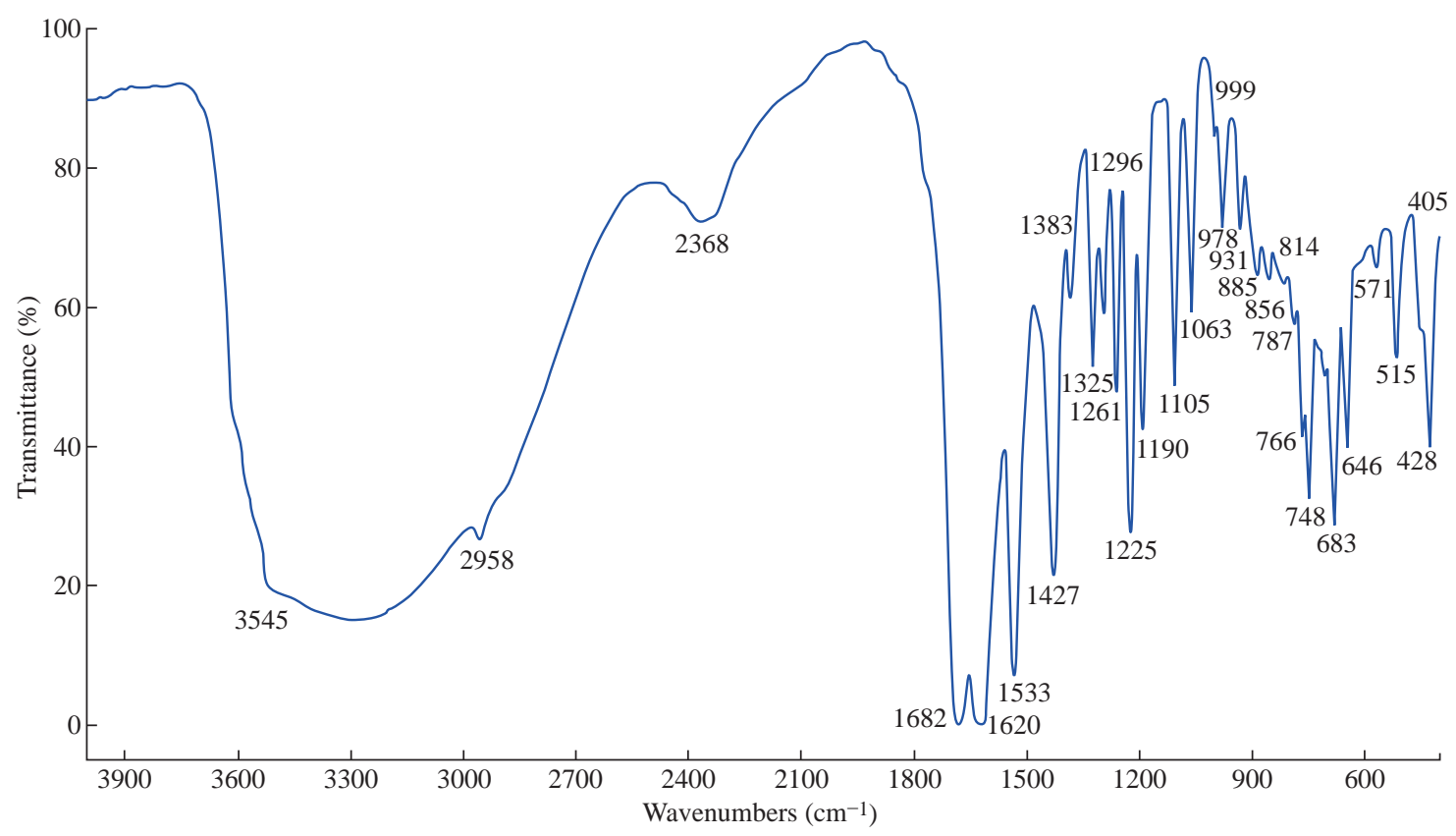

Fig. 2 FTIR spectrum of the $\left[\mathrm{Cu}(\mathrm{THP})_{2}\left(\mathrm{H}_{2} \mathrm{O}\right)_{4}\right]$ nano complex. 

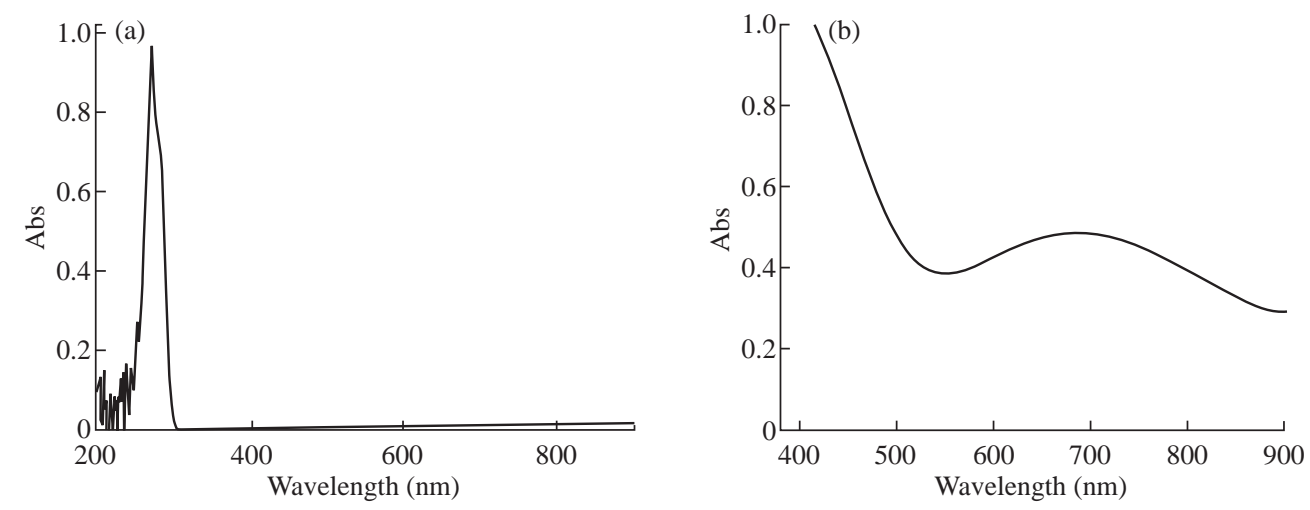

Fig. 3 (a) The UV-Vis spectra of $\left[\mathrm{Cu}(\mathrm{THP})_{2}\left(\mathrm{H}_{2} \mathrm{O}\right)_{4}\right]$ complex at low concentration and (b) only visible spectra at high concentration.
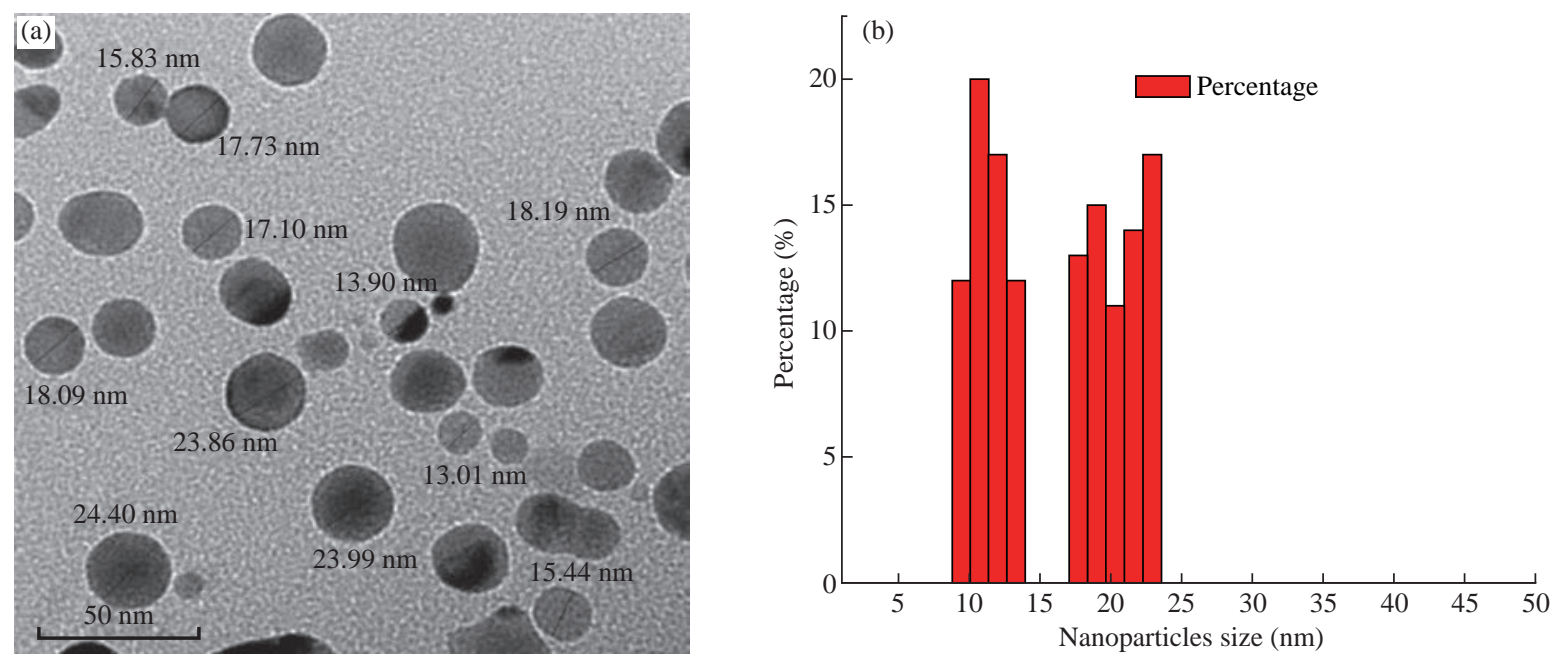

Fig. 4 (a) TEM of $\left[\mathrm{Cu}(\mathrm{THP})_{2}\left(\mathrm{H}_{2} \mathrm{O}\right)_{4}\right]$ nano complex and (b) particle size distribution of Nano complex.

The transmission electron microscopy (TEM) measurement shows that the size of the particle is to be $20 \mathrm{~nm}$. The sample was free from any aggregation, and the dimensions in the synthesized complex were within the nanoscale (less than $100 \mathrm{~nm}$ ), which indicates that the type of nano is the particle and zero size, which is widely preferred in preparing nanoscales (Fig. 4).

\section{Effect of nanomedicine complex $\left[\mathrm{Cu}(\mathrm{THP})_{2}\left(\mathrm{H}_{2} \mathrm{O}\right)_{4}\right]$ on phosphodiesterase (PDE) activity}

Nano-biotechnologies are a 21st-century emerging field. In recent years, NPs have gained more considerable attention due to their unique and distinctive properties, intermediate to individual molecules and bulk matter. The use of copper compound NPs in gas sensors, hot transfer fluids, catalytic systems, solar energy, and batteries has been significant alongside other metal NPs [36-39]. Copper compound NPs can find various applications in agriculture, health care, and industry due to their antimicrobial activities. The growth, by opening many huddled doors in pathophysiology and therapy, of
Nano-compounds has altered many medical concepts. In the pharmacological field, where the compound is antibacterial, antioxidants, anticancer, and so on, its apparent effects on an organism's biological molecules have not concealed, copper compounds in nanoscale play an essential role [40-47]. The more important thing is because the Surface Plasmon Resonance (SPR) of the copper nanoscale varies from other Nano compounds, which, due to interactivity between the conduction electrons of copper NPs and incident photon, represents a resonance effect. The interaction is based on copper NPs size and shape, and the scatter media's design and composition [48, 49].

One of the essential current diseases is asthma. This is one of the most prevalent inflammatory disorders in humans and impacts the people of all ages and cultural groups. Asthma has characterized by wheezing, tightness of the chest, and breathing difficulty [50]. The pathophysiological variation of asthma is triggered by several cell-specific interactions, which induce immunological response followed by airflow obstruction and, thus, by many inflammatory 
cytokines. An asthma diagnosis is based on the signs and symptoms of asthma. It is highly evident that these chronic and the most prevalent illnesses are detected and avoided early [51-53]. In asthma patients who kill cyclic extracellular nucleotides, PDE serum levels are increased, PDEs typically disrupt the phosphate groups, and cAMP or cGMP in target cells have decreased [54, 55]. The effect of copper Nanocomplex on enzyme phosphodiesterase activity (PDE) in human serum patients with asthma disease had shown in the present study in Table 1 and Fig. 5.

Table 1 Phosphodiesterase level in sera of controls and asthma patients

\begin{tabular}{ccc}
\hline Groups & $\begin{array}{c}\text { Phosphodiesterase }(\mathrm{ng} / \mathrm{mL}) \\
\text { Mean } \pm \text { SD }\end{array}$ & P-value \\
\hline Control patients & $9.974 \pm 2.032$ & $<0.01$ \\
(without treatment) & $14.939 \pm 3.021$ & \\
Control Patients with & $9.974 \pm 2.032$ & $<0.01$ \\
treatment (theophylline) & $11.253 \pm 2.479$ & \\
Control Patients with & $9.974 \pm 2.032$ & $>0.05$ \\
treatment (Nano complex) & $9.563 \pm 2.082$ & \\
Patients without treatment Patients & $14.939 \pm 3.021$ & $<0.01$ \\
with treatment (theophylline) & $11.253 \pm 2.479$ & \\
Patients without treatment Patients & $14.939 \pm 3.021$ & $<0.01$ \\
with treatment (Nano complex) & $9.563 \pm 2.082$ & \\
Theophylline & $11.253 \pm 2.479$ & $<0.01$ \\
nano complex & $9.563 \pm 2.082$ & \\
P $<0.01:$ Highly significant; $p>0.05:$ Non-significant & \\
\hline
\end{tabular}

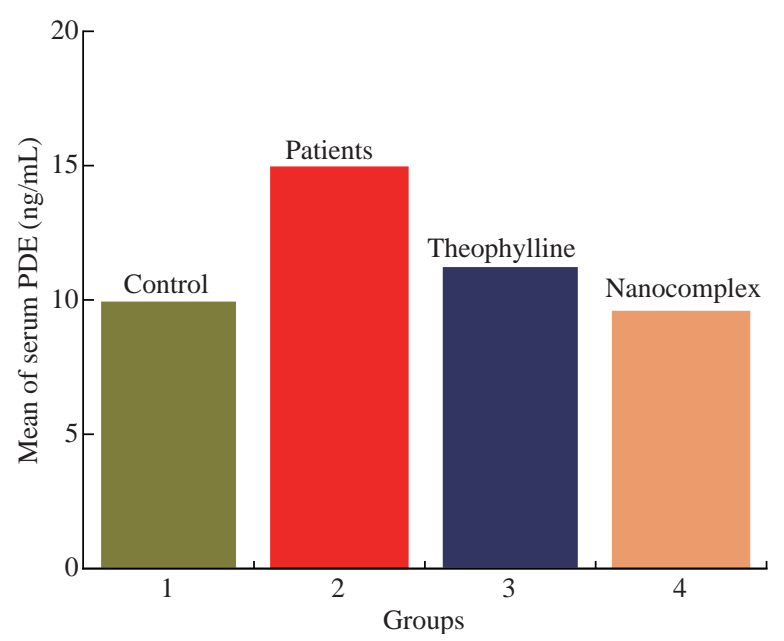

Fig. 5 Phosphodiesterase level in sera of controls and asthma patients.

The results have shown a highly significant $(p<0.01)$ increase in the serum levels of phosphodiesterase enzyme activity in asthma patients (mean = $14.939 \pm 3.021 \mathrm{ng} / \mathrm{mL}$ ) compare with a control group (mean $=9.974 \pm 2.032 \mathrm{ng} / \mathrm{mL})$, The increase of PDE enzyme on the asthma patients have reported in many studies [56, 57]. The result also has shown a highly significant $(\mathrm{p}<0.01)$ decrease in the serum levels of phosphodiesterase activity in patients of asthma disease with theophylline $($ mean $=11.253 \pm 2.479 \mathrm{ng} / \mathrm{mL})$ compared to serum patients without nano and control groups. The vital thing in this study that has shown in the result a highly significant $(\mathrm{p}<0.01)$ decrease in the serum levels of phosphodiesterase activity in patients of asthma disease with copper nano complex (mean $=9.563 \pm 2.082 \mathrm{ng} / \mathrm{mL}$ ) compared in patients of asthma disease with and without theophylline. The clinical action of theophylline and theophylline nano complexes on phosphodiesterase enzyme of patients with asthma disease does cause bronchodilation through a chemical process that binds the smooth muscle. This results in an inhibition of the PDE action that separates cyclic nucleotides into the cells and increases extracellular levels of cyclic monophosphate adenosine (cAMP) and cyclic monophosphate guanosine (cGMP). This contributes to an expansion of the muscles> smoothness [58-62]. As for comparing asthma disease with copper nano complex and control group, the resulting has shown there was no significant effect $(p>0.05)$.

\section{Conclusions}

The ultrasonic sonication method has used to synthesize complex in nanoscale. Our method has a display that the nanocomplex can easily be synthesized without aggregation. The size of NPs obtained in this study is $20 \mathrm{~nm}$. The present work is the first study that explains the effect of copper nanocomplex on the activity of Phosphodiesterase (PDE) in 160 samples of sera for Iraqi patients with asthma diseases. The results have shown that the $\left[\mathrm{Cu}(\mathrm{THP})_{2}\left(\mathrm{H}_{2} \mathrm{O}\right)_{4}\right]$ in nanoscale had an inhibition effect on the enzyme activity highly. The impact on the enzyme activity in Asthma patients shows that the nanomedicine complex $\left[\mathrm{Cu}(\mathrm{THP})_{2}\left(\mathrm{H}_{2} \mathrm{O}\right)_{4}\right]$ has more inhibition effect than theophylline $(\mathrm{p}<0.01)$.

\section{Acknowledgments}

This work was supported by the Chemistry Department, college of science, Mustansiriyah University.

\section{Conflict of Interests}

The authors declare that no competing interest exists. 


\section{References}

[1] C. Zhang, C. Du, J.Y. Liao, et al., Synthesis of magnetite hybrid nanocomplexes to eliminate bacteria and enhance biofilm disruption. Biomaterials science. 2019, 7(7): 2833-2840

[2] A.F. Kamil, H.I. Abdullah, A.M. Rheima, et al., Modification of hummers presses for synthesis graphene oxide nano-sheets and graphene oxide/Ag nanocomposites. Journal of Ovonic Research. 2021, 17(3).

[3] M.A. Mohammed, A.M. Rheima, S.H. Jaber, et al., The removal of zinc ions from their aqueous solutions by $\mathrm{Cr}_{2} \mathrm{O}_{3}$ nanoparticles synthesized via the UV-irradiation method. Egyptian Journal of Chemistry, 2020, 63(2): 425431.

[4] A.M. Rheima, M.A. Mohammed, S.H. Jaber, et al., Inhibition effect of silver-calcium nanocomposite on alanine transaminase enzyme activity in human serum of Iraqi patients with chronic liver disease. Drug Invention Today, 2019, 12(11): 2818-2821.

[5] N.A. Aboud, B.E. Jasim, A.M. Rheima. Adsorption study of phosphate ions pollution in aqueous solutions using microwave synthesized magnesium oxide nanoparticles. Digest Journal of Nanomaterials and Biostructures. 2021, 16(3).

[6] D.H. Hussain, A.M. Rheima, S.H Jaber, Cadmium ions pollution treatments in aqueous solution using electrochemically synthesized gamma aluminum oxide nanoparticles with DFT study. Egyptian Journal of Chemistry, 2020, 63(2): 417-424.

[7] A.M. Rheima, R.S. Mahmood, D.H. Hussain, et al., Study the Adsorption Ability of Alizarin Red Dye From Their Aqueous Solution on Synthesized Carbon Nanotubes. Digest Journal of Nanomaterials and Biostructures, 2020, 15(4).

[8] A.F. Kamil, H.I. Abdullah, A.M. Rheima, et al., Impact of $\mathrm{Fe}_{2} \mathrm{NiO}_{4}$ nanoparticles to increase efficiency of dyesensitized solar cells. Materials Today: Proceedings. 2021.

[9] N.A. Aboud, W.M. Salih, D.H. Hussain, et al., A comparative study of $\mathrm{ZnO}$, $\mathrm{CuO}$ and a binary mixture of $\mathrm{ZnO}_{0.5}-\mathrm{CuO}_{0.5}$ with nano-dye on the efficiency of the dye-sensitized solar cell. 2020 J. Phys.: Conf. Ser. 1664012094.

[10] A.H. Ismail, H.K. Al-Bairmani, Z.S. Abbas, et al., Nano-synthesis, spectroscopic characterisation and antibacterial activity of some metal complexes derived from theophylline. Egyptian journal of chemistry, 2020, 63(12).

[11] A.F. Kamil, H.I. Abdullah, A.M. Rheima, et al., UVIrradiation synthesized $\alpha-\mathrm{Fe}_{2} \mathrm{O}_{3}$ nanoparticles based dyesensitized solar cells. Materials Today: Proceedings. 2021.

[12] A.F. Kamil, H.I. Abdullah, A.M. Rheima, et al., Cibacron red dye removal in aqueous solution using synthesized $\mathrm{CuNiFe}_{2} \mathrm{O}_{5}$ Nanocomposite: Thermodynamic and kinetic studies. Egyptian Journal of Chemistry. 2021, 64(11): 5-6.

[13] Abdulah HI, Hussain DH, Rheima AM. Synthesis of $\alpha-\mathrm{Fe}_{2} \mathrm{O}_{3}, \gamma-\mathrm{Fe}_{2} \mathrm{O}_{3}$ and $\mathrm{Fe}_{3} \mathrm{O}_{4}$ Nanoparticles by Electrochemical Method. Journal of Chemical, Biological and Physical Sciences, 6(4): 1288-1296

[14] A.A. Ali, R.M. Al-Hassani, D.H. Hussain, et al., Synthesis, spectroscopic, characterization, pharmacological evaluation, and cytotoxicity assays of novel nano and micro scale of copper (II) complexes against human breast cancer cells. Drug Invention Today, 2020, 14(1): 31-39.

[15] H.A. Kadhum, W.M. Salih and A.M. Rheima. Improved $\mathrm{PSi} / \mathrm{C}-\mathrm{Si}$ and $\mathrm{Ga} / \mathrm{PSi} / \mathrm{C}-\mathrm{Si}$ nanostructures dependent solar cell efficiency. Applied Physics A, 2020, 126(10): 1-5.

[16] A.H. Ismail, H.K. Al-Bairmani, Z.S. Abbas , et al., Synthesis, Characterization, Spectroscopic and Biological Studies of $\mathrm{Zn}(\mathrm{II}), \mathrm{Mn}(\mathrm{II})$ and Fe(II) Theophylline Complexes in Nanoscale. Nano Biomed. Eng., 2020, 12(3): 253-261.

[17] S.N. Aziz, M.F. Al Marjani, A.M. Rheima, et al., Antibacterial, antibiofilm, and antipersister cells formation of green synthesis silver nanoparticles and graphene nanosheets against Klebsiella pneumoniae. Reviews in Medical Microbiology, 20219.

[18] A.M. Rheima, A.A Anber, A. Shakir, et al., Novel method to synthesis nickel oxide nanoparticles for antibacterial activity. Iranian Journal of Physics Research, 2020, 20(3): 51-55.

[19] H. Suojalehto, K. Suuronen, P. Cullinan, et al., Phenotyping Occupational Asthma Caused by Acrylates in a Multicenter Cohort Study. The Journal of Allergy and Clinical Immunology: In Practice, 2019.

[20] P. Aghasafari, U. George, and R. Pidaparti. A review of inflammatory mechanism in airway diseases. Inflammation Research, 2019, 68(1): 59-74.

[21] M.R. Edwards, S. Saglani, J. Schwarze, et al., Addressing unmet needs in understanding asthma mechanisms: From the European Asthma Research and Innovation Partnership (EARIP) Work Package (WP) 2 collaborators. European Respiratory Journal, 2017, 49(5): 1602448.

[22] B. Singh. Asthma and chronic obstructive pulmonary disorder-phytomedicine. International Journal of Green Pharmacy (IJGP), 2017, 11(3).

[23] C. Page, B. O'Shaughnessy, and P. Barnes. Pathogenesis of COPD and asthma. Pharmacology and Therapeutics of Asthma and COPD, Springer, Cham, 2016: 1-21.

[24] K. Samitas, A.Carter, H.H. Kariyawasam, et al., Upper and lower airway remodelling mechanisms in asthma, allergic rhinitis and chronic rhinosinusitis: The one airway concept revisited. Allergy, 2018, 73(5): 993-1002.

[25] H. Levine, M. Cohen-Cymberknoh, N. Klein, et al., Reversible airway obstruction in cystic fibrosis: Common, but not associated with characteristics of asthma. Journal of Cystic Fibrosis, 2016, 15(5): 652-659.

[26] A.H. Ismail, H.K. Al-Bairmani, Z.S. Abbas, et al., Synthesis, characterization, spectroscopic, and biological activity studies of Nano scale Zn(II), Mn (II) and Fe (II) theophylline complexes. Journal of Xi'an University of Architecture \& Technology, 2020, XII(II): 2775-2789.

[27] G.A. Burdock, I.G. Carabin, and C.M. Crincoli. Safety assessment of kola nut extract as a food ingredient. Food and chemical toxicology, 2009, 47(8): 1725-1732.

[28] H.C. Andersson, H. Hallström, and B.A. Kihlman. Intake of caffeine and other methylxanthines during pregnancy and risk for adverse effects in pregnant women and their foetuses. Nordic Council of Ministers, 2004.

[29] H.J. Smit. Theobromine and the pharmacology of cocoa. Methylxanthines, Springer, Berlin, Heidelberg, 2011: 201234.

[30] M. Zydron, J. Baranowski, and I. Baranowska, J. Sep. Sci., 2004, 27: 116-1172.

[31] D. Spina, C.P. Page, Xanthines and phosphodiesterase inhibitors. Pharmacology and Therapeutics of Asthma and COPD, Springer, Cham, 2016: 63-91.

[32] B. Victoria, M. Cazzola, and C.P. Page. Are phosphodiesterase 4 inhibitors just more theophylline? Journal of allergy and clinical immunology, 2006, 117(6): 1237-1243.

[33] A.H. Ismail, H.K. Al-Bairmani, Z.S. Abbas, et al., Nanoscale synthesis of metal (II) theophylline complexes and assessment of their biological activity. Nano Biomed. Eng., 2020, 12(2): 139-147.

[34] P. Zou, S.S. Oh, P. Hou, et al., Simultaneous determination of synthetic phosphodiesterase-5 inhibitors 
found in a dietary supplement and pre-mixed bulk powders for dietary supplements using high-performance liquid chromatography with diode array detection and liquid chromatography-electrospray ionization tandem mass spectrometry. Journal of Chromatography A, 2006, 1104(1-2): 113-122.

[35] GACKI, Michał, Synthesis, characterisation, crystal structure and biological activity of metal (II) complexes with theophylline. Journal of Saudi Chemical Society, 2019, 23(3): 346-354.

[36] A.M. Rheima, N.A. Aboud, B.E. Jasim, et al., Synthesis and structural characterization of $\mathrm{ZnTiO}_{3}$ nanoparticles via modification sol-gel prosses for assessment of their antimicrobial activity. International journal of pharmaceutical research, 2021, 13(1) 342-347.

[37] A.H. Ismail, H.K. Al-Bairmani, Z.S. Abbas, et al., Nano metal-complexes of theophylline derivative: synthesis, characterization, molecular structure studies, and antibacterial activity. IOP Conf. Ser.: Mater. Sci. Eng., 2020, 928: 052028.

[38] A.M. Rheima, A.A. Anber, H.I. Abdullah, et al., Synthesis of Alpha-Gamma Aluminum Oxide Nanocomposite via Electrochemical Method for Antibacterial Activity. Nano Biomed. Eng., 2021, 13(1): 1-5.

[39] A.M. Rheima, D.H. Hussain, and H.J. Abed, Fabrication of a new photo-sensitized solar cell using $\mathrm{TiO}_{2} / \mathrm{ZnO}$ Nanocomposite synthesized via a modified sol-gel Technique. IOP Conference Series: Materials Science and Engineering. IOP Publishing, 2020, 928(5): 052036)..

[40] A.F. Kamil, H.I. Abdullah, A.M. Rheima, et al., Photochemical synthesized $\mathrm{NiO}$ nanoparticles based dyesensitized solar cells: a comparative study on the counter electrodes and dye-sensitized concentrations. Journal of Ovonic Research, 2021, 17(3): 299-305.

[41] M. Al Marjani, S.N. Aziz, A.M. Rheima, et al., Impact of Chromium oxide Nnanoparticles on Growth and Biofilm Formation of Persistence Klebsiella pneumoniae Isolates. Nano Biomed. Eng, 2021, 13(3): 321-327.

[42] S.H. Mohammed, A. Rheima, F. Al-jaafari, et al., Greensynthesis of Platinum Nanoparticles using Olive Leaves Extracts and its Effect on Aspartate Aminotransferase Activity. Egyptian Journal of Chemistry, 2021.

[43] N.A. Aboud, B.E. Jasim, and A.M. Rheima, Methylene Orange dye removal in aqueous solution using synthesized $\mathrm{CdO}-\mathrm{MnO}_{2}$ nanocomposite: kinetic and thermodynamic studies. Chalcogenide Letters, 2021, 18(5): 237-243.

[44] A.T. Salman, A.H. Ismail, A.M. Rheima, et al., NanoSynthesis, characterization and spectroscopic Studies of chromium (III) complex derived from new quinoline2-one for solar cell fabrication. Journal of Physics: Conference Series, 2021, 1853(1): 012021.

[45] M. Rad, M.Taran and M. Alavi. Effect of incubation time, $\mathrm{CuSO}_{4}$ and glucose concentrations on biosynthesis of copper oxide $(\mathrm{CuO})$ nanoparticles with rectangular shape and antibacterial activity: Taguchi method approach. Nano Biomed Eng., 2018, 10(1): 25-33.

[46] M. Alavi, N. Karimi, and T. Valadbeigi. Antibacterial, antibiofilm, antiquorum sensing, antimotility, and antioxidant activities of green fabricated $\mathrm{Ag}, \mathrm{Cu}, \mathrm{TiO}_{2}$, $\mathrm{ZnO}$, and $\mathrm{Fe}_{3} \mathrm{O}_{4}$ NPs via protoparmeliopsis muralis lichen aqueous extract against multi-drug-resistant bacteria. ACS Biomaterials Science \& Engineering, 2019, 5(9): 42284243.

[47] M. Alavi, N.Karimi. Biosynthesis of Ag and Cu NPs by secondary metabolites of usnic acid and thymol with biological macromolecules aggregation and antibacterial activities against multi drug resistant (MDR) bacteria. International Journal of Biological Macromolecules,
2019, 128: 893-901.

[48] M. Alavi, N. Karimi, Antiplanktonic, antibiofilm, antiswarming motility and antiquorum sensing activities of green synthesized $\mathrm{Ag}-\mathrm{TiO}_{2}, \mathrm{TiO}_{2}-\mathrm{Ag}, \mathrm{Ag}-\mathrm{Cu}$ and $\mathrm{Cu}-$ Ag nanocomposites against multi-drug-resistant bacteria. Artificial Cells, Nanomedicine, and Biotechnology, 2018, 46(sup3): S399-S413.

[49] M. Hirai, A. Kumar. Wavelength tuning of surface plasmon resonance by annealing silver-copper nanoparticles. Journal of Applied Physics, 2006, 100(1): 014309.

[50] T. Ghodselahi, M.A.Vesaghi, and A. Shafiekhani, Study of surface plasmon resonance of $\mathrm{Cu} @ \mathrm{Cu}_{2} \mathrm{O}$ core-shell nanoparticles by Mie theory. Journal of Physics D: Applied Physics, 2008, 42(1): 015308

[51] J. Stern, J. Pier, and A.A. Litonjua, Asthma epidemiology and risk factors. Seminars in Immunopathology, 2020: $1-11$.

[52] X. Cui, Z. Li, Y. Teng, et al., Association Between Bedroom Particulate Matter Filtration and Changes in Airway Pathophysiology in Children With Asthma. JAMA Pediatrics, 2020, 174(6): 533-542

[53] H.H. Tang, P.D. Sly, Systems biology and big data in asthma and allergy: recent discoveries and emerging challenges. European Respiratory Journal, 2020, 55(1).

[54] A. Bush. Pathophysiological mechanisms of asthma. Frontiers in Pediatrics, 2019, 7: 68.

[55] O.A. Carpaij, J.K. Burgess, H.A. Kerstjens, et al., A review on the pathophysiology of asthma remission. Pharmacology \& Therapeutics, 2019, 201: 8-24.

[56] A.M. Chinn, P.A. Insel. Cyclic AMP in dendritic cells: A novel potential target for disease-modifying agents in asthma and other allergic disorders. British Journal of Pharmacology, 2020.

[57] C.D Lee, W.S. Choi, Y.G. Choi, et al., Inhibition of phosphodiesterase suppresses allergic lung inflammation by regulating MCP-1 in an OVA-induced asthma murine model with co-exposure to lipopolysaccharide. Journal of International Medical Research, 2020, 48(2).

[58] P. Ntontsi, A. Detta, P. Bakakos, et al., Experimental and investigational phosphodiesterase inhibitors in development for asthma. Expert Opinion on Investigational Drugs, 2019, 28(3): 261-266.

[59] T. Southworth, M. Kaur, L. Hodgson, et al., Antiinflammatory effects of the phosphodiesterase type 4 inhibitor CHF6001 on bronchoalveolar lavage lymphocytes from asthma patients. Cytokine, 2019, 113: 68-73.

[60] T.N. Jilani, C.V. Preuss, and S. Sharma, Theophylline. Stat Pearls Internet, 2019.

[61] M. Talmon, E. Massara, C. Brunini, et al., Comparison of anti-inflammatory mechanisms between doxofylline and theophylline in human monocytes. Pulmonary Pharmacology \& Therapeutics, 2019, 59: 101851.

[62] F. Liu, Y. Zhang, J. Schafer, et al., Diaphragmatic recovery in rats with cervical spinal cord injury induced by a theophylline nanoconjugate: Challenges for Clinical Use. The journal of Spinal Cord Medicine, 2019, 42(6): 725-734.

Copyright $₫$ Zainab Sabri Abbas, Ahmad Hussein Ismail, Hassanain Kamil Al-Bairmani, Ahmed Mahdi Rheima, Ameer Radhi Sultan, and Srwa Hashim Mohammed. This is an openaccess article distributed under the terms of the Creative Commons Attribution License, which permits unrestricted use, distribution, and reproduction in any medium, provided the original author and source are credited. 